УДК 811.161.1'37

DOI 10.23951/1609-624X-2020-3-104-113

\title{
РЫНОК И БАЗАР: ДИНАМИКА ФРАГМЕНТА ЛЕКСИКОНА
}

\author{
В. Д. Черняк, Е. В. Парышева
}

Российский государственный педагогический университет им. А. И. Гериена, Санкт-Петербург

\begin{abstract}
Введение. Слова рынок и базар стали своеобразными индикаторами социальных, экономических и политических изменений, оказавших значительное влияние на языковую личность носителя русского языка. Целью статьи является рассмотрение динамики фрагмента тезауруса, вербализованного словами рынок и базар, на основе анализа лексикографических и корпусных источников.

Материал и методы. Материалом статьи являются данные толковых словарей с XVIII по XXI век, материалы ассоциативных словарей и фрагменты текстов, извлеченные из Национального корпуса русского языка, позволяющие на основе сопоставительного анализа выявить динамические процессы в семантике лексем.

Результаты и обсуждение. Сопоставление материалов толковых словарей и «Русского ассоциативного словаря» убеждает, что «зеркало ассоциативного словаря» незаменимо для исследования отдельных фрагментов действительности, взаимосвязи ассоциативных и системных лексико-семантических полей. Исследование в направлении от системы и ассоциативно-вербальной сети к тексту показало, как постепенно меняется семантическая структура двух синонимов, как осуществляется их аксиологическая специализация. У слова рынок со временем развивается новое значение - «сфера товарообмена», что в дальнейшем отражается на расширении лексической сочетаемости. Актуализация семантического компонента «шум» приводит появлению у слова бaзар переносного значения - «громкий разговор». Базар в сознании носителя языка - пространство, где могут обмануть. Рынок на ценностной шкале обыденного сознания также связывается с воровством, дороговизной и хаосом, что во многом обусловлено влиянием на языковое сознание социально-экономических факторов. Семантические различия двух синонимов и контаминация разных значений служат основанием для создания языковой игры.

Заключение. Семантика слов рынок и базар, вербализующих значимый для жизни человека фрагмент действительности, на протяжении длительной истории их бытования в русском языке претерпела значительные трансформации, обнаруживающиеся и на уровне структуры значений, закрепленных лексикографически, и на ассоциативно-вербальном уровне языковой личности. В семантической структуре слова рынок наблюдается все более заметное преобладание нового значения (система товарно-денежных отношений) над традиционным (место торговли). Лексема базар во всех значениях оказывается коннотативно отмеченной.
\end{abstract}

Ключевые слова: лексикография, лексическая семантика, ассоџиативное поле, коннотации, синонимия.

\section{Введение}

Меняющаяся языковая картина современного мира обнаруживается как в совокупных изменениях лексикона нашего современника, так и в динамике отдельных значимых ее фрагментов, заданных «ключевыми словами текущего момента» [1]. К таким фрагментам языковой картины мира, без сомнения, относится концептуальное пространство, вербализованное лексемами рынок и базар.

На русскую речь конца XX - начала XXI в. несомненное влияние оказали перестройка экономических отношений в России и глобализация экономики на мировом уровне [2, с. 15]. Слова рынок и базар, выражение рыночная экономика стали своеобразными индикаторами социальных, экономических и политических изменений, оказавших значительное влияние на язык и социум и, следовательно, на языковую личность носителя русского языка. Актуализируются не только сами слова $p b l-$ нок и базар, но и их отдельные семантические компоненты, наблюдается трансформация значений на семном уровне, изменяется и семантическая струк- тура лексем, имеющих давнюю историю в русском языке.

Целью данной статьи является рассмотрение динамики фрагмента тезауруса, вербализованного словами рынок и базар. Безусловное сходство семантики этих слов не исключает, а скорее предполагает все более значимую актуализацию различий. Лексикографические издания, фиксирующие семантические изменения исследуемых лексических единиц с XVIII по XXI в., а также материалы Национального корпуса русского языка дают объективные основания для интерпретации значимых динамических процессов. Чрезвычайно важны материалы ассоциативных словарей, позволяющие моделировать вербальную память и языковое сознание «усредненного» носителя русского языка [3, с. 197]. Соединение в исследовании лексикографических данных, «вербальных ассоциаций и самих ассоциативных полей» [4, с. 12], а также материалов текстов, отражающих дискурсивные практики нашего современника, дает основание для исследования того, как изменения в объективной действительности отражаются в семантике лексических единиц. 


\section{Результаты и обсуждение}

Слово базар в русском языке впервые зафиксировано в XV в. и имеет персидское происхождение, гораздо позже появляются его дериваты (базарный - в XVIII в., базарить - в начале XIX в.). Слово рынок в русском языке известно с начала XVIII в. и, предположительно, заимствовано из немецкого через западнославянские языки [5].

«Словарь Академии Российской» фиксирует тесные синонимические связи слов базар и рынок. Словарная статья базар помимо описательного толкования («Так называется место или площадь, на которую съезжаются еженедельно по установленным дням, в городах и в некоторых селах, из окрестных жительств поселяне для продажи хлеба и изделий своих и для покупки нужных себе вещей») содержит ссылку на словарную статью $p b-$ нок, слово же рынок толкуется через синонимы базар и торжище [6]. «Словарь церковно-славянского и русского языка» (1847 г.) закрепляет в семантике слова базар значимый компонент - «постоянное место торга» [7].

«Толковый словарь живого великорусского языка» В. И. Даля содержит многие народные речения, указывающие на представления носителей языка о фрагментах действительности, так или иначе связанных с базаром (Плох базар, коли хлеба купить не на что; Где баба, там рынок: где две, там базар; Три бабы - базар, а семь-ярмарка) [8]. Примечательно, что впервые у слова базар фиксируется значение «крик, гам, шум». Базар актуализирует признаки непостоянного, неосновательного, в некоторых случаях праздного. В семантике дериватов (базарник - «озорник», «праздный гуляка»; бaзарить, базариться - «громко разговаривать, кричать, шуметь, браниться»; базарщина - «базарная толпа; || плохая работа, непрочная вещь») актуализируются негативные семы «несерьезный», «шумный», «плохое качество». При этом слово рынок и его дериваты отрицательных коннотаций лишены.

K XX в. семантическое поле с ядерными лексемами базар и рынок, их дериватами, а также лексемами ярмарка, торг, торжище, барахолка («толкучий рынок»), толкучка вполне сложилось и в силу значительного прагматического потенциала оказалось открытым для семантических изменений.

«Толковый словарь русского языка» под редакцией Д. Н. Ушакова, отражая те изменения, которые произошли в языковом сознании носителей русского языка после революции под влиянием смены политического строя и коренной перестройки всего социума, внес идеологические компоненты и в словарные статьи исследуемых лексем, фиксируя идеологический компонент при формировании новых устойчивых словосочетаний (колхозный базар, рыночный комитет) или отмечая устаревшие в новых условиях единицы (Благотворительный базар (дореволюи.) - распродажа..., <...> устраивавшаяся представительницами привилегированных классов). Впервые в словарную статью включено новое терминологическое значение рынок как сфера товарооборота с закономерной для этого словаря идеологической маркировкой речения (Борьба империалистических стран за рынки) [9].

Значительные изменения затронули лексическую семантику обоих слов. Первоначальное восприятие «базарного» как чего-то несерьезного, неосновательного, а также праздного и веселого, несколько меняется. Теперь слово базарный в переносном значении означает прежде всего «бранный», «непристойный», что ранее отмечалось В. И. Далем в одном из речений: базарная, площзадная брань. Словарем фиксируется устойчивое сочетание базарная баба («крикливая, склонная к скандалам женщина»). У слова рынок закрепляется переносное значение, связанное с громким разговором, шумом. Дериваты слова базар утрачивают значение «плохо сделанный».

Отметим, что и другие толковые словари советского времени в основном сохраняют и семантическую характеристику исследуемых слов, и идеологическую маркированность некоторых речений [10].

«Толковый словарь русского языка» С. И. Ожегова и Н. Ю. Шведовой, появившийся в 1992 г., воплотил лексикографический отклик на перестроечные процессы. Так, исчезли речения колхозный базар и колхозный рынок, связанные с уходящими реалиями советского прошлого, появилось ранее «чуждое» блошиный рынок («разг. рынок, на к-ром продаются старые поношенные вещи, мелкие товары с рук»), связанное с актуализацией еще одного элемента поля - барахолки [11].

Новый «Большой академический словарь русского языка» (БАС), создаваемый уже в третьем тысячелетии, ставит своей целью отразить состояние лексики русского языка с XIX по начало XXI в. [12]. По данным словаря, наибольшие изменения коснулись слова рынок и его деривата рыночный. Несмотря на то, что в семантической структуре слова первым по-прежнему остается «пространственное» значение, синонимичное слову базар, наибольшее развитие получает именно второе значение, связанное с товарооборотом, спросом и предложением. Это выражается прежде всего в закреплении и распространении новых устойчивых сочетаний (теория рынка, рынки сбыта, рыночнылй оборот, рыночные отночения, рыночная экономи$\kappa a)$. Впервые в словаре закрепляется выражение черный рынок [13]. 
Для слова базар следует отметить появление в толковании семы «кустарные промыслы» («торговля продуктами, изделиями кустарных промыслов и т. п., осуществляемая по определенным дням или ежедневно в специально отведенном для этого месте»). Кроме того, исчезают некоторые малоупотребительные дериваты (базарник, базарница, базарщина), актуализируются отдельные значения, связанные с торговлей (базарить не только «громко разговаривать», но и «торговать»; базарничать «продавать на базаре» и «перепродавать»).

Как уже отмечалось, особое значение для исследования фрагментов тезауруса имеют ассоциативные словари. Еще в 70-е гг. XX в. А. А. Леонтьев в предисловии к «Словарю ассоциативных норм русского языка» писал: «Если нам нужно найти метод, с наибольшей объективностью позволяющий вскрыть „культурную“ специфику словарных единиц, вскрыть те побочные, непосредственно не релевантные для обобщения семантические связи, которые имеет данное слово, его семантические „обертоны“, - без сомнения, таким методом является ассоциативный эксперимент, а ближайшим источником данных на этот счет - словарь ассоциативных норм» $[14$, с. 14$]$.

Наиболее полный на сегодняшний день «Русский ассоциативный словарь» моделирует вербальную память и языковое сознание «усредненного» носителя русского языка и дает богатейший материал для разноаспектных лингвистических исследований. Он открывается очень точными словами «От редакции»: «Русский ассоциативный словарь приоткрывает завесу над тем, как устроена языковая способность человека - думающего, говорящего и понимающего. Она позволяет проникнуть в социально-историческую память носителя русского языка и получить ответ на вопрос: „Как мыслят русские в современной России“» $[15$, с. 3]. В этих «напутственных» для потенциального пользователя словах намечается чрезвычайно значимый антропоцентрический вектор возможных исследований.

Слово рынок вошло в список слов-стимулов второго этапа ассоциативного эксперимента (1996 г.) и представлено в третьей книге «Русского ассоциативного словаря:

РЫНОК: базар 9; сбыта 7; свободный 4; толкучка, черный 3; Басманный, большой, вещевой, дорого, дорогой, на уличе, Птичий 2; абсурда, армян, армяне, бизнес, близко, богатый, брокер, Бутырский, вещей, воры, все дорого, гниль, города, городской, грузин, дело тонкое, деньги, дешевый, дикий, дорога, за углом, зеленый, и успех, идти на рынок, капитала, капитализм, колхозный, крытый, купить, латы, Ленинского района, мировой, музей, мясной, на площади, неуправляемый, общественный, общий, Омск, отношения, переход, пой- ти, привоз, прилавок, продукты, пуст, пустой, путники, разнообразие, регулируемый, Рижский, рыло, советский, спрос, технологий, товары, толчок, торговый иентр, труда, угроза, иветы, иенных бумаг, Центральный, иены, иирк, экономический, юг $1 ; 110+79+3+67$.

Анализ ассоциативного поля показывает, что испытуемые актуализируют разные значения, соотносят языковой знак с разными денотатами. Первое значение («Сфера товарного обращения, товарооборота») вызывает наиболее частотные реакции: сбыта, свободный, толкучка, черный. В сочетании со стимулом они образуют устойчивые сочетания ( ные в политическом и экономическом дискурсах. Реакция черный (черный р.) указывает на то, что в сознании носителя русского языка в 90-е гг. XX в. актуализируется такая черта рыночных отношений переходной эпохи, как их нелегальный характер.

Единичные реакции также служат индикатором отношения носителей языка к понятию, выражаемому словом-стимулом. Ср.: абсурда (рынок абсурда); дикий (дикий рынок); и успех (рынок и успех), неуправляемый (неуправляемый рынок), угроза (рынок - это угроза), ичирк (рынок - это как цирк). Эти реакции являются отражением экономической ситуации переходного периода, разрушения старой системы товарно-денежных отношений и нарождения новой, пока еще нестабильной, а потому вызывающей непонимание в социуме. Реакция регулируемый «извлекает» из памяти испытуемого достаточно частотное в 90-е гг. словосочетание регулируемый рынок, указывающее на противоречивость экономической ситуации тех лет: противники резких реформ выступали не за доминирование свободного рынка, а за регулируемый рынок, построенный на отличных от капитализма принципах. Реакция капитализм, вызвана ценностными установками, характерными для большинства носителей языка того времени: переход к рыночной экономике связывался в противовес коммунизму с капитализмом. Реакция торговый иентр связана с появлением и распространением новых мест торговли - торговых центров, чью функцию раньше выполняли рынки, базары, универсальные магазины. Среди реакций нередко встречаются названия конкретных мест торговли (Басманный, Птичий, Бутырский, Рижский).

Примечательна реакция колхозный (колхозный рынок), прямо соотносимая с типичным речением, приводимым в толковых словарях советской эпохи. Колхозные рынки были официально действующими торговыми площадками в СССР, где колхозники имели право сбывать излишки продукции. Особенными, можно сказать, жизненно важными, оказывались колхозные рынки в переломные для 
общества моменты: во время войн, в эпоху застоя, распада СССР они становились «институтом выживания» для огромных масс людей [16, с. 102]. В связи с этим актуализация словосочетания колхозный рынок (являвшегося к тому же официальным наименованием подобных мест в городах) в конце 80-х - начале 90-х оказывается закономер-

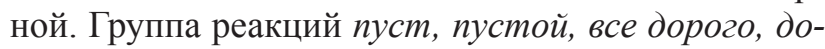
рого, дорогой выразительно представляет реалии начала 90-х гг. Реакции воры и гниль отражают негативную оценку, с одной стороны, продаваемых на рынке продуктов, а с другой - неблагонадежных посетителей или продавцов.

Весьма интересной является группа реакций армян, армяне, грузин, дело тонкое, юг, актуализирующая представления носителей языка о торгующих на рынке. Рынок ассоциативно связывается с представителями южных и восточных этносов, а также с концептом юг. В этой связи актуализируется и реакция дело тонкое (компонент прецедентного высказывания Восток дело тонкое). «Этнические рынки» появились гораздо позже регулируемых государством колхозных и вещевых рынков: в 1960-1980-х гг. на них выделился заметный слой выходцев с Кавказа, началось формирование «образа кавказца» - человека, не только отличающегося особенностями культуры, внешности и поведения, но и олицетворяющего в категориях тех лет «торгашество» [16, с. 103].

Таким образом, испытуемые чаще реагируют в эксперименте на стимул рынок в значении «место торговли». В сознании носителя русского языка 90-х гг. ХХ в. рынок наделяется такими качествами, как ненадежность, дороговизна, обман, что говорит о негативном в целом восприятии новой экономической и социальной ситуации.

Слово базар вошло в список слов-стимулов третьего, последнего этапа ассоциативного эксперимента (1998 г.) и появилось в пятой книге «Русского ассоциативного словаря»:

БАЗАР: рынок 20; большой, вокзал, народ, разговор 4; гнилой, торговля 3; восток, птичий, pbночный, товар, толкучка, толпа, шум 2; + толпа, бабий, базарить, базарная площадь, барахолка, беспорядок, бессмысленный разговор, богатый, в иентре, вещевой, восточныий, городской, громкий, грязный, грязь, деньги, деревенский, казанский, калоша, кончать, люди, не по теме, обман, овощей, овощи, отдаленныцй, покупка, полный, продукты, пронзительный, птии, рынок (разговор), рыночная экономика, славянский, сплетни, суматоха, тетка, толчея, толчок, торговать, узбек, фильтровать, фильтруй, черный, шумный, ярмарка 1; $103+60+1+46$.

Наиболее частотной реакцией является слово рынок, что говорит о сильных синонимических связях в сознании носителей языка слова-стимула и слова-реакции. Отношения частичной семантической равнозначности, или синонимии, также наблюдаются в реакциях толкучка, барахолка и толчок, а также отчасти ярмарка. Согласно словарю С. И. Ожегова и Н. Ю. Шведовой, ярмарку от база$p a$ отличает то, что на ней помимо торговли есть и развлечения [11].

Базар как место торговли приводит к массовому скоплению людей в одном пространстве, что порождает суматоху и толчею. Для носителей языка базар - это торговое место, обычно занимающее большую площадь, полное различных товаров, наполненное людьми, обычно грязное. В ассоциативном поле представлены названия конкретных базаров: казанский, славянский. Актуализируются и пространственные отношения: вокзал, базарная площчадь, в иеентре, городской, отдаленный. Появление реакции вокзал объясняется схожестью признаков, присущих обоим понятиям: и на база$p e$, и на вокзале большое количество людей, что порождает суету, шум, столпотворение. Кроме того, так же, как и у слова рынок, у слова базар в сознании носителя языка сильны ассоциативные связи с востоком: восток, восточный, узбек.

Примечательна реакция рыночная экономика. В 1990-е гг. слово базар используется для обозначения стихийной спекулятивной российской экономики в период перехода к рыночным отночениям [17]. Появление такой реакции объясняется и спецификой изменений в социально-экономической сфере, произошедших в 90-е гг. ХХ в. Слово рынок используется для объективного описания системы общественных отношений, основанных на свободном товарообращении без оценки характера такой системы, в то время как стихийная, нерегулируемая, непредсказуемая система часто вербализовалась словом базар [17].

Второе значение (жум, крик) актуализируется в реакциях: бессмысленный разговор, шум; разговор; бабий, базарить, громкий, не по теме, кончать, пронзительный, рынок (разговор), сплетни, тетка, фильтровать, фильтруй, шумный.

Таким образом, в ассоциативном поле базар наиболее частотны реакции, актуализирующие значение «место розничной торговли», среди них, в свою очередь, выделяются реакции, указывающие на синонимические связи слова-стимула и словареакции, а также лексические единицы, служащие для наименования признаков такого места торговли.

Сопоставление материалов толковых словарей и «Русского ассоциативного словаря» убеждает, что «зеркало ассоциативного словаря» незаменимо для исследования отдельных фрагментов действительности, взаимосвязи ассоциативных и систем- 
ных лексико-семантических полей. Ассоциативный словарь «позволяет установить своеобразие процессов семантизации в сознании носителя языка» $[18$, с. 176].

Осуществление значимого для исследования динамических процессов в семантике лексических единиц перехода от системы и ассоциативно-вербальной сети к тексту становится возможным при использовании богатейших возможностей Национального корпуса русского языка [19].

Анализ исследуемых единиц проводился по следующим подкорпусам: 1) материалы XVIII в.; 2) материалы XIX века (до 1889 г.); 3) материалы конца XIX - начала XX в. (1890-1921); 4) советский период (1922-1991); 5) постсоветский период (с 1992 г. по настоящее время).

Выборки XVIII в. относительно небольшие: 33 вхождения для слова базар и 101 вхождение для слова рынок. Слово базар употребляется в контекстах, содержащих указание на временный характер торга, при этом упоминаются конкретные дни, когда базар проводится: Лавки отворяют по понедельникам в базар (А. Н. Радищев. Записки путешествия в Сибирь (1790)). В некоторых контекстах выражены пространственные отношения: Велел запрячь и ехать на базар (М. П. Загряжский. Записки (1770-1811)). Перечисляются конкретные товары, продаваемые на базаре: На базаре продают хлеб свой, рыбу из Сибири, свежую и соленую, хмель из России, сено, дрова, масло льняное, лен, оглобли, горики чугунники, патоку, сало (А. Н. Радищев. Записки путешествия в Сибирь (1790)).

Слово рынок также употребляется для выражения пространственных отношений: И для того-то всегда любимая моя прогулка по обжорному рынку (И. А. Крылов. Пирог (1799-1801)). В текстах часто перечисляются объекты купли-продажи: $B$ своему городе в ярмоночные повсенедельные дни в рынки продают сено, дрова, тес, доски, брусья, строевой лес, и родяшиеся в их лесах всякие ягоды и грибы (П. И. Челищев. Путешествие по северу России в 1791 г (1791)).

Примечателен текст, в котором открыто указывается на то, что для обстановки на рынке характерна брань, хотя изначально такая коннотация впервые появляется и закрепляется у слова базар: Если же называть его станет именованиями смрадными и бранныли словами поносить, как то на рынках употребительно, то сие есть личность, но язвительная и недозволенная (А. Н. Радищев. Путешествие из Петербурга в Москву (17791790)).

Выборка XIX в. содержит около 1100 вхождений слова базар. Сохраняется актуализация пространственных отношений, отношений купли-продажи с указанием конкретных товаров, нередко указывается связь базаров с городом, городской жизнью. Базары - это место столпотворений. Ср: По четвергам базары бывают, так и не проехать, что туда народу наезжает! (М. Е. Салтыков-Щедрин. Тихое пристанище (1857-1865)); Большой здесь город, народу на базаре, барок на реке страсть! (М. Е. Салтыков-Щедрин. Почехонская старина. Житие Никанора Затрапезного, пошехонского дворянина (1887-1889)).

Базары часто связываются с обманом, слухами, воровством, мошенничеством: Сльиш, париивая команда, не воровать на базаре! (Н. Г. Помяловский. Очерки бурсы (1862)); Между тем лазутчики геријога, Остермана и Ушакова усердно шныряли повсюду: они втирались в дома, забирались в присутственные места и казармы, шлялись по кабакам, рынкам, базарам, баням, гуляньям и харчевням, подслушивая, о чем толкует народ и вызывая людей словоохотливых на опасныле речи, привлекавшие болтливых на расправу в тайную канцелярию (Е. П. Карнович. Любовь и корона (1879)).

Частотно выражение благотворительньй базар, закрепленное в словаре под редакцией Д. Н. Ушакова с пометой «дореволюционное»: Когда начался сезон, она записалась в несколько филантропических обществ, усиленно стала посещзать баль, театры, клубы, кониерты, торговала на благотворительных базарах, играла в благотворительных спектаклях... (А. И. Эртель. Две пары (1887)); Или что-нибудь этакое общественное, базар с благотворительною ичелью например? Это деловой костюм: серенькое или черное платье, совериенно скромное. Ну, конечно, возвышенное место, где разложены различные безделушки, - она продает, все смотрят, покупают... (А. О. Осипович (Новодворский). Накануне ликвидации (1880)).

Рассмотрим материалы выборки для слова pblнок, относящиеся к 1801-1889 гг. При сохранении семантики пространственных отношений и отношений купли-продажи наблюдаются изменения. Появляется множество контекстов, указывающих на нарождающееся, хотя и не очень распространенное значение «товарообмен», «товарно-денежные отношения»: Но Рукодеев и торговался не похоже на других купиов: он не божился, не упраиивал сбавить и пожалеть, не хлопал с ожесточением по рукам, а ссылался на положение рынка в Лондоне, на чрезмерное развитие овцеводства в Австралии... (А. И. Эртель. Гарденины, их дворня, приверженџы и враги (1889)); Вся же остальная промышленная братия ничего не измыслила по части рынка, кроме того, чтобы валить свои продукты в Астрахань. (Г. И. Успенский. Из цикла «Очерки переходного времени» (1889)); $\mathrm{Mbl}$ во все верим: верим в силу закона, в силу городового положения, в силу рынка, фабриканта, в силу исправ- 
ника, адвоката, прокурора и -никогда, никогда в силу обыкновенного, простого человеческого сознания (Н. Н. Златовратский. Город рабочих (1885)).

Аналогично базару рынок воспринимается как многолюдное, но грязное место, играющее большую роль в жизни города. Это не только место торговли, но и сфера социальной коммуникации. На рынке распускают слухи, есть вероятность быть обманутым, купить некачественный, плохой товар: Но грязь, вонь и тряпье такая необходимая принадлежность всех городских рынков, что мы не считаем нужным входить во все подробности описания этой живой клоаки (Д. Н. Мамин-Сибиряк. Бойц̧ы (1883)); Старый хозяин мой распустил про меня по рынку слух, что я его на левую ногу обделал, на руку не чист и штуку полотна стянул (Н. А. Лейкин. Из записной книжки отставного приказчика Касьяна Яманова (1874)); Слово рынок в гостинодворском языке есть нечто унизительное: товар рыночнылй, товар кустарный-значит, или товар плохой отделки, или порченый, или вышедший из обыкновенной продажи (Ф. В. Булгарин. Гостиный двор (1843)).

Актуализируются названия известных рынков, расположенных в Москве, Петербурге или других крупных городах: Походил по городу, затем пришел на Апраксин рынок (И. Д. Путилин. 40 лет среди грабителей и убийц (1889)); Прошлое почти одинаковое: пришла на Хитров рынок наниматься; у нее нарочно, чтобы закабалить ее, «кот» украл паспорт... (В. А. Гиляровский. Трущзобные люди / «Каторга» (1887)); Человек «в этаком виде» был то, что называется «верзило»; на обертках лубочных изданий Никольского рынка в таком именно виде изображают обыкновенно фигуpы «витязей»... (Г. И. Успенский. Из путевых заметок (1889)); - Тут и Смоленский рынок близковесь воздух протухлой рыбой провонял (М. Е. Салтылко-Щедрин. Мелочи жизни (1886-1887)).

У слова базар конца XIX - начала XX сохраняется пространственная семантика и семантика купли-продажи, а также наблюдаются негативные коннотации, которые актуализируются при характеристике обстановки на базаре (людей, товаров): На базаре было грязно, завалено конским навозом, валялось тряпье, кухонные отбросы, и собаки грызли кости (А. С. Серафимович. Скитания (1913)).

Базар - это по-прежнему место обмана, слухов, воровства, недоверия людей друг другу: Eмy казалось, что весь воздух базара пропитан сухой злостью, все пьянеют от нее и острого недоверия друг к другу, все полны страха быть обманутыми и каждый хочет обмануть - словно здесь, на маленькой площчади, между пожарною каланчою и церкковною колокольнею, в полукруге низеньких торговых рядов, сошлись чуждые друг другу, враждебные племена (Максим Горький. Жизнь Матвея Кожемякина (1910)). Кроме того, фиксируется небольшое количество контекстов, в которых слово базар употреблено в значении «разговор», в составе словосочетания «кончить базар»: Будь другие обстоятельства, непреоборимые, я бы, поверь, смело сказал тебе: ну что же, Женя, пора кончить базар... (А. И. Куприн. Яма (1909-1915)).

У слова рынок продолжает развиваться семантический компонент «товарообмен», «товарно-денежные отношения»: Я около четырех лет тщзательно изучал положение русской кожи на заграничных рынках (Максим Горький. Фома Гордеев (1899)); Книжка, разумеется, пошла очень туго, потому что была издана без всяких соображений с потребностью рынка (И. Н. Потапенко. Не герой (1891)); Промышленность не иссякнет до тех пор, пока будет рынок сбыта (Л. А. Чарская. Золотая рота (1911)).

В текстах советского периода слова базар и pblнок используются в связи с коллективным хозяйством и колхозной продукцией: За то, что он колхозник! Рыннк-то - колхозный! (Э. Рязанов, Эмиль Брагинский. Вокзал для двоих (1983)); Он уходил на берег Умары, бродил по колхозному рынку, а последней школьной весной, когда надо было готовиться к выпускным экзаменам, полюбил остров Дятлинку.... (Б. Черныхх. Остров Дятлинка (1978) // Библиотека «Огонек», 1988); Но два дня в неделю у нее были выходныли: в воскресенье она чтото покупала на базаре у колхозников, а в понедельник продавала - то же самое (Г. Троепольский. Бельий Бим черное ухо (1971)).

Сохраняется негативное восприятие базара как шумного места, где могут обмануть, обворовать: Спокойно, мужики, - говорил Николай Григорьевич, - мы же не на базаре (В. Шукиин. Выбираю деревню на жительство (1972-1973)); Ходили на базар, воровали там что могли... (В. Некрасов. Взгляд и Нечто (1977)).

Продукция на базаре и рынке очень часто оценивается как чрезмерно дорогая: Я ходил по городу. Базар был скудный, а иены непомерно высокие (С. М. Голииьни. Записки беспогонника (19461976)); Буханка хлеба на базаре - восемьсот рублей (Г. Я. Бакланов. Навеки девятнадияатилетние (1979)); Больиих денег на базаре мыло стоит. (Виктор Астафьев. Царь-рыба (1974)); Приходилось покупать рыбу на рынке по безумной цене (И. Грекова. Фазан (1984)).

Чрезвычайно распространенным становится выражение «черный рынок»: Доставала с рук, на черном рынке. В доме стали мельтешить бородатые и очкастые юниь, книжные маклеры, кото- 
рые наряду с редкой книгой могли торгануть и какой-нибудь дефиичтной ветошью, например, бельми водолазками из ГУМа с наценкой пять рублей. Милая публика! Раза два я вытурял их из дома (Ю. Трифонов. Предварительные итоги (1970)).

В приведенном фрагменте очень показательны все элементы текстового поля рынок (маклеры, торгануть, дефицитная ветошь, наценка), демонстрирующие актуальную для советского периода аксиологию, связанную с концептом рынок.

Существенные изменения происходят в текстах постсоветской эпохи. Рынок, еще мало насыщенный товарами и часто криминальный, по-прежнему оценивается негативно. Ср.: < ..> Ира сериалов не смотрела, и даже не из принципа, просто это было выше ее сил, хуже чтения детективов, вываленных на ранний практически пустой постсоветский рынок мало отягоштвшими себя обозначенной хотя бы пунктиром моралью издательствами... (Г. Маркосян-Каспер. Кариатиды // «Звезда», 2003)); И вместе с подружками, с которыми училась на курсах, принялась похаживать на рынок, выпрашивать торгашеское занятие, трясти перед покупателем хозяйским товаром (В. Распутин. Дочь Ивана, мать Ивана // «Наш современник», 2003.11.15)); Проверить догадались только, удобно ли его везти: предыдущчий, купленный на вещзевом рынке (барахолке по-старому), из той же экономии (сомнительной: потом выяснилось, что на заграничных распродажах такие точно стоят раза в два дешевле) все время заваливался набок (О. Новикова. Мне страшно, или Третий роман // «Звезда», 2003). Формируемое текстовое поле также наполняется лексикой с отрицательной коннотацией (торгашеское занятие, пустой, трясти хозяйским товаром, сомнительная экономия и т. п.). Примечательно и актуальное сопоставление: барахолка-заграничная распродажа.

Базар по-прежнему воспринимается как шумное, многолюдное место, где можно не только торговать, но и обмениваться новостями, слухами. Это место, где хаотично смешиваются разные люди, разнородные явления. Ср.: Базар кипит, гниет, бурлит и крутит человеческую массу, спрессовывает тысячи голодных и сотни сытых в черно-серую халву; ползет толпа вдоль длинных, наспех сколоченных прилавков с награбленным добром и смутно-годным мусором: покойницкая мятая одежда, сорочки с кружевами, детское белье, иарманки, граммофонь, самовары, утюги... (С. Самсонов. Одиннадияать (2010)).

Часто лексемы рынок и базар используются в одном контексте, при этом актуализация различий синонимов, контаминация разных значений создают языковую игру: Tym нет никакого рынка. Базар был, во-он там, у метро (Е. Прошкин. Эвакуация (2002)); Что мне твой рынок на нашем базаре! (Н. Крыиук. Отступление // «Звезда», 2003); Для рассеянного уха (равнодушного, благополучного, популистски настроенного или просто глупого) всякий рынок звучит базаром. Не правильнее ли было бы именовать «рыночные отночения» иначе: «свободными отношениями»? Путаемся в терминологии и переносим путанииу в практику нашей реальной жизни (В. Аграновский. Вторая древнейшая. Беседы о журналистике (1976-1999)).

В то же время новые экономические отношения обусловливают все большее расширение лексической сочетаемости слова рынок в значении «сфера товарообмена»: Kрупные корпорации, - вдруг сказал Димка профессорским тоном, - вкладьвают большие деньги и большие усилия в развитие брэндов и продвижение их на рынке (Т. Устинова. Подруга особого назначения (2003)); Они уже сегодня половину московского нефтяного рынка окучивают, а скоро весь покроют (С. Данилюк. Бизнескласс (2003)); Валютный рылнок, - как раз пропльл за бортом, - не принял тебя! (В. Попов. Свободное плавание // «Звезда», 2003); Я боюсь нашей системы здравоохранения, нашей медицинской бюрократии, рынка лекарств (С. Есин. Марбург (2005)); То ли долгая жизнь в браке, то ли свободный рынок так закаляет человека, но я вдруг без всякого перехода рубанул... (А. Щербаков. Пах антилопь // «Октябрь», 2002).

\section{Заключение}

Семантика слов рынок и базар, вербализующих значимый для жизни человека фрагмент действительности, на протяжении длительной истории их бытования в русском языке претерпела значительные трансформации. Они обнаруживаются на уровне структуры значений, закрепленных лексикографически, на ассоциативно-вербальном уровне языковой личности, о чем свидетельствуют данные ассоциативных словарей, и в совокупности текстов, отражающих разнообразные дискурсивные практики. Исследованный материал подтверждает положение о корреляции трех типов полей системных, ассоциативных и текстовых [20].

Развитие семантики двух изначально предельно близких слов свидетельствует о все большей их семантической специализации. $\mathrm{B}$ семантической структуре слова рынок наблюдается все более заметное преобладание нового значения (система товарно-денежных отношений) над традиционным (место торговли). Лексема базар во всех значениях оказывается коннотативно отмеченной. Носители языка все чаще «сталкивают» два синонима, противопоставляя семы «порядок» и «отсутствие порядка». 


\section{Список литературы}

1. Шмелева Т. В. Кризис как ключевое слово текущего момента // Политическая лингвистика. 2009. Вып. 2 (28). С. $63-67$.

2. Ратмайр Р. Русская речь и рынок: Традиции и инновации в деловом и повседневном общении. М.: Языки славянской культуры, 2013. 456 с.

3. Козырев В. А., Черняк В. Д. Лексикография русского языка: век нынешний и век минувший. СПб.: Изд-во РГПУ им. А. И. Герцена, 2015. 631 с.

4. Мартинович Г. А. Текст и эксперимент: исследование коммуникативно-тематического поля в русском языке. СПб.: Изд-во СПбГУП, 2008. 256 с.

5. Черных П. Я. Историко-этимологический словарь современного русского языка: в 2 т. М.: Рус. яз., 1999.

6. Словарь Академии Российской: 1789-1794: в 6 т. / гл. ред. Г. А. Богатова. М.: Моск. гуманит. ин-т им. Е. Р. Дашковой, 2001-2006. T. 1-6.

7. Словарь церковно-славянского и русского языка, составленный Вторым Отделением Императорской Академии наук. Т. 1-4. СПб.: Тип. Императ. Акад. Наук, 1847.

8. Даль В. И. Толковый словарь живого великорусского языка: в 4 т. Репр. воспроизв. изд. 1912-1914. М.: Цитадель, 1998.

9. Толковый словарь русского языка: в 4 т. / сост. В. В. Виноградов [2-4 тт.], Г. О. Винокур, Б. А. Ларин, С. И. Ожегов, Б. В. Томашевский, Д. Н. Ушаков; под ред. Д. Н. Ушакова [Воспр. изд. 1935-1940 гг.]. М.: Русские словари, 1994. Т. 1-4.

10. Ожегов С. И. Словарь русского языка. 9-е изд., испр. и доп. (около 57000 слов). 1972. 846 с.

11. Ожегов С. И., Шведова Н. Ю. Толковый словарь русского языка: 72500 слов и 7500 фразеологических выражений. М.: Азъ, $1992.955 \mathrm{c}$.

12. Большой академический словарь русского языка / гл. ред. К. С. Горбачевич, А. С. Герд. М.; СПб.: Наука, $2005-2014$.

13. Черняк В. Д. БАС: история слова - история лексикографии, история страны // Слово. Словарь. Словесность: Динамические процессы в языке, речи и словаре (к 50-летию издания академического «Словаря современного русского литературного языка»): материалы Всерос. науч. конф. Санкт-Петербург, РГПУ им. А. И. Герцена, 11-12 ноября 2015 г. / отв. ред. В. Д. Черняк. СПб.: САГА, 2016. С. 5-10.

14. Словарь ассоциативных норм русского языка / под ред. А. А. Леонтьева. М.: Изд-во Моск. гос. ун-та, 1977. 192 с.

15. Русский ассоциативный словарь: в 6 кн. / Ю. Н. Караулов, Ю. А. Сорокин, Е. Ф. Тарасов, Н. В. Уфимцева, Г. А. Черкасова. 1994-1998.

16. Дятлов В. И. Постсоветские рынки под открытым небом: новый феномен или продолжение традиции? // Сибирские исторические исследования. 2017. № 1. С. 99-118.

17. Новые слова и значения. Словарь-справочник по материалам прессы и литературы 90-х годов ХХ века: в 2 т. / отв. ред. Т. Н. Буцева. СПб.: Дмитрий Буланин, 2009.

18. Норман Б. Ю. От семы через доминантный признак - к прототипу // Новая Россия: традиции и инновации в языке и науке о языке: материалы докл. и сообщ. междунар. науч. конф. М.; Екатеринбург: Кабинетный ученый, 2016. С. 167-178.

19. НКРЯ - Национальный корпус русского языка. URL: http:/www.ruscorpora.ru/new/ (дата обращения: 03.01.2020).

20. Ильина О. С., Черняк В. Д. Принцип поля в исследовании фрагмента действительности // Проблемы интерпретационной лингвистики: поле как объект и инструмент исследования. Новосибирск, 2011. С. 16-27.

Черняк Валентина Данииловна, доктор филологических наук, профессор, Российский государственный педагогический университет им. А. И. Герцена (Небережная р. Мойки, 48, Санкт-Петербург, 191186). E-mail: vdcher@yandex.ru

Парышева Екатерина Викторовна, магистрант, Российский государственный педагогический университет им. А. И. Герцена (Небережная р. Мойки, 48, Санкт-Петербург, 191186). E-mail: cancor@bk.ru

Материал поступил в редакиию 06.02.2020.

DOI 10.23951/1609-624X-2020-3-104-113

\section{RYNOK (MARKET) AND BAZAR (BAZAAR): THE DYNAMICS OF LEXICON FRAGMENT}

\section{D. Chernyak, E. V. Parysheva}

Herzen State Pedagogical University of Russia, Saint Petersburg, Russian Federation

Introduction. The words rynok (market) and bazar (bazaar) have become a kind of indicators of social, economic and political changes, which had a great impact on language personality of the Russian native speaker. The aim of the article is to research into the dynamics of thesaurus fragment, which is verbalized with words rynok (market) and bazar (bazaar). The analysis is based on lexicographical and corpus data. 
Methods and material. The main material used for analysis is: data taken from explanatory dictionaries published from XVIII to XXI century, associative fields mined from associative dictionaries, and text fragments extracted with the help of The Russian National Corpus. These materials make juxtaposition analysis of lexical semantics dynamic processes possible.

Results and discussion. Juxtaposition of explanatory dictionaries materials as well as "Russian Associative Dictionary" shows that 'the mirror of associative dictionary' is indispensable for studying particular fragments of reality. Interconnection between associative fields and systemic lexical semantics fields is obvious. The study directed from system to text shows the gradual changes in semantics structure of two synonyms. The research traces the establishment of their axiological specialization. The word rynok (market) develops a new meaning over time - "sphere of commodity exchange", which is further reflected in the expansion of its lexical compatibility. Since the semantic component "noise" actualizes, the figurative meaning of word bazar (bazaar) emerges - "loud conversation". Bazar (bazaar) in the native speaker's mind is a space where one can be easily deceived. Rynok (market) on the value scale of everyday consciousness is also associated with theft, high cost and chaos, which is largely due to the influence of socio-economic factors on the language consciousness. Semantic differences between two synonyms and contamination of different meanings become the basis for creating language game.

Conclusion. The meaning of words rynok (market) and bazar (bazaar) verbalize the crucial for person's life fragment of reality. Throughout the long history of functioning, their semantics underwent significant transformation that can be revealed at various levels: structure of the meanings fixed by lexicography, associative and verbal level of language personality. The observations show that in the semantics structure of word rynok (market) the new meaning ('system of exchange relations') tends to prevail over the traditional one ('place for trade'). Lexical unit bazar (bazaar) contains connotations in all meanings.

Keywords: lexicography, lexical semantics, associative field, connotations, synonymy.

\section{References}

1. Shmeleva T. V. Krizis kak klyuchevoye slovo tekushchego momenta [Crisis as a Keyword of the Current Moment]. Politicheskaya lingvistika - Political Linguistics, 2009, no. 2 (28). pp. 63-67 (in Russian).

2. Ratmayr R. Russkaya rech'i rynok: Traditsii i innovatsii v delovom i povsednevnom obshchenii [Russian Speech: Traditions and Innovations in Business Communication]. Moscow, Yazyki slavyanskoy kul'tury Publ., 2013. 456 p. (in Russian).

3. Kozyrev V. A., Chernyak V. D. Leksikografiya russkogo yazyka: vek nyneshniy i vek minuvshiy [Lexicography of the Russian Language: the Present Century and the Past Century]. Saint Petersburg, Herzen State Pedagogical University of Russia Publ., 2015. 631 p. (in Russian).

4. Martinovich G. A. Tekst i eksperiment: issledovaniye kommunikativno-tematicheskogo polya v russkom yazyke [Text and Experiment: Study of Communicative and Theme Field in the Russian Language]. Saint Petersburg, SPbGUP Publ., 2008. 256 p. (in Russian).

5. Chernykh P. Ya. Istoriko-etimologicheskiy slovar'sovremennogo russkogo yazyka: v 2 t. [Historical and Etymological Dictionary of the Modern Russian Language: 2 volumes]. Moscow, Rus. yaz. Publ., 1999 (in Russian).

6. Slovar'Akademii Rossiyskoy: 1789-1794: v 6 t. [The Dictionary of the Russian Academy: 1789-1794: 6 vol.]. Moscow, Mosk. gumanit. in-t im. E. R. Dashkovoy Publ., 2001-2006. Vol. 1-6 (in Russian).

7. Slovar'tserkovno-slavyanskogo i russkogo yazyka, sostavlennyy Vtorym Otdeleniyem Imperatorskoy Akademii nauk. T. 1-4 [The Dictionary of the Church Slavonic and Russian Language Composed by the $2^{\text {nd }}$ Department of the Emperor's Academy of Sciences. Vol. 1-4]. Saint Petersburg, Tip. Imperat. Akad. Nauk Publ., 1847 (in Russian).

8. Dal' V. I. Tolkovyy slovar'zhivogo velikorusskogo yazyka: V 4 t. Repr. vosproizv. izd. 1912-1914 [The Explanatory Dictionary of the Alive Great Russian language: 4 vol., edition 1912-1914]. Moscow, Tsitadel' Publ., 1998. (in Russian).

9. Tolkovyy slovar' russkogo yazyka: $v 4$ t. Sost. V. V. Vinogradov, G. O. Vinokur, B. A. Larin, S. I. Ozhegov, B. V. Tomashevskiy, D. N. Ushakov; pod red. D. N. Ushakova. Vospr. izd. 1935-1940 gg. [The Explanatory Dictionary of the Russian Language: 4 vol. Compiled by V.V. Vinogradov [2-4 vols.], G. O. Vinokur, B. A. Larin, S. I. Ozhegov, B. V. Tomashevsky, D. N. Ushakov; under the editorship of D. N. Ushakova;]. Moscow, Russkiye slovari Publ., 1994. T. 1-4 (in Russian).

10. Ozhegov S. I. Slovar' russkogo yazyka. 9-e izd., ispr. i dop. (okolo 57000 slov) [The Dictionary of the Russian Language. Academy of Sciences of the USSR, Institute of the Russian Language. Ed. 9, rev. and suppl. (about 57,000 words)]. 1972. 846 p. (in Russian).

11. Ozhegov S. I., Shvedova N. Yu. Tolkovyy slovar' russkogo yazyka: 72500 slov i 7500 frazeologicheskikh vyrazheniy. Ros. akad. nauk, In-t rus. yaz., Ros. fond kul'tury [The Explanatory Dictionary of the Russian Language: 72500 Words and 7500 Idioms. Russian Academy of Sciences, Institute of the Russian Language, Russian Culture Foundation]. Moscow, Az” Publ., 1992. 955 p. (in Russian).

12. Gorbachevich K. S. (Editor-in-chief), Gerd A. S., Balakhonova L. I. (ed.), Kruglikova L. E., Solov'ev N. V., Pankov D. I. Bol’shoy akademicheskiy slovar' russkogo yazyka [The Big Academic Dictionary of the Russian Language. Russian Academy of Sciences]. Moscow, Saint Petersburg, Nauka Publ., 2005-2014 (in Russian).

13. Chernyak V. D. BAS: istoriya slova - istoriya leksikografii, istoriya strany [BAD: History of the Word - History of Lexicography, History of Country]. Slovo. Slovar'. Slovesnost': Dinamicheskiye protsessy v yazyke, rechi i slovare (k 50-letiyu izdaniya aka- 
demicheskogo "Slovarya sovremennogo russkogo literaturnogo yazyka"): materialy Vseros. nauch. konf. Sankt-Peterburg, RGPU im A. I. Gertsena, 11-12 noyabrya 2015 g. [Word. Dictionary. Philology: Dynamic Processes in Language, Speech, and Culture (to $50^{\text {th }}$ Anniversary of Academic Edition of "The Dictionary of the Modern Russian Language"): materials of the Russian National Scientific Conference, St. Petersburg, Herzen State Pedagogical University of Russia, November 11-12, 2015]. Saint Petersburg, 2016. Pp. 5-10 (in Russian).

14. Leont'ev A. A., Klimenko A. P., Suprun A. E. (compl.), Leontiev A. A. (ed.) Slovar'assotsiativnykh norm russkogo yazyka [The Dictionary of Associative Standards of the Russian Language]. Moscow, Moscow State University Publ., 1977. 192 p. (in Russian).

15. Karaulov Yu. N., Sorokin Yu. A., Tarasov E. F., Ufimtseva N. V., Cherkasova G. A. Russkiy assotsiativnyy slovar': v 6 kn. [The Russian Associative Dictionary: 6 volumes]. 1994-1998 (in Russian).

16. Dyatlov V. I. Postsovetskiye rynki pod otkrytym nebom: novyy fenomen ili prodolzheniye traditsii? [Post-Soviet Open Air Markets: the New Phenomenon or the Continuation of Traditions?]. Sibirskiye istoricheskiye issledovaniya - Siberian Historian Research, 2017, no. 1, pp. 99-118 (in Russian).

17. Butseva T. N., Levashov E. A., Denisenko Yu. F. (compilers), Butseva T. N. (Executive editor). Novye slova i znacheniya. Slovar'spravochnik po materialam pressy i literatury 90-kh godov XX veka: $v 2 t$. [The New Words and Meanings. Reference Dictionary Based on Materials of Press and Literature of the 90s of the XX century. Institute of Linguistic Studies, RAS]. Saint Petersburg, DMITRIY BULANIN Publ., 2009 (in Russian).

18. Norman B. Yu. Ot semy cherez dominantnyy priznak - k prototipu [From Seme Through Dominant Feature to Prototype]. In: Novaya Rossiya: traditsii i innovatsii v yazyke i nauke o yazyke: materialy dokl. i soobshch. mezhdunar. nauch. konf. [New Russia: Traditions and Innovations in Language and Language Science: material of reports and messages of the international scientific conference]. Moscow, Ekaterinburg, Kabinetnyy uchenyy Publ., 2016. Pp. 167-178 (in Russian).

19. NKRYa - Natsional'nyy korpus russkogo yazyka [The Russian National Corpus] (in Russian). URL: http://www.ruscorpora.ru/ new/ (accessed 3 January 2020).

20. Il'ina O. S., Chernyak V. D. Printsip polya v issledovanii fragmenta deystvitel'nosti [The Field Principle in the Study of Reality Fragment]. In: Problemy interpretatsionnoy lingvistiki: pole kak ob"ekt $i$ instrument issledovaniya [Problems of Interpretative Linguistics: The Field as an Object and an Instrument of Research]. Novosibirsk, 2011. Pp. 16-27 (in Russian).

Chernyak V. D., doctor of philology, professor, Herzen State Pedagogical University of Russia (nab. r. Moyki, 48, Saint Petersburg, Russian Federation, 191186).E-mail: vdcher@yandex.ru

Parysheva E. V., master's degree student, Herzen State Pedagogical University of Russia (nab. r. Moyki, 48, Saint Petersburg, Russian Federation, 191186).E-mail: cancor@bk.ru 